\title{
THE TAGGING OF RED CELLS AND PLASMA PROTEINS WITH RADIOACTIVE CHROMIUM ${ }^{1}$
}

\author{
By SEYMOUR J. GRAY AND KENNETH STERLING 2 \\ (From the Biophysical Laboratory and the Department of Medicine, Harvard Medical School, \\ and the Medical Clinic, Peter Bent Brigham Hospital, Boston)
}

(Submitted for publication July 31, 1950; accepted, September 21, 1950)

Relatively few reports have appeared on the chromium content of biological material. Previous studies were devoted primarily to the analysis of plants and soils (1).

In preparation for the present study, arc spectrography ${ }^{3}$ was used to demonstrate the presence of trace amounts of chromium in human tissues, including the blood. Tissue analyses were performed on samples of normal human blood by means of a colorimetric method (2) with the finding of mean values of $20 \gamma \%$ for packed red cells and $14 \gamma \%$ for plasma.

The present report is concerned with a new biological tracer, radioactive chromium $\left(\mathrm{Cr}^{51}\right)$, which is bound by the red cells and plasma proteins. Both anionic hexavalent $\left(\mathrm{Na}_{2} \mathrm{Cr}^{51} \mathrm{O}_{4}\right)$ and cationic trivalent $\left(\mathrm{Cr}^{51} \mathrm{Cl}_{3}\right)$ states of the element have been studied.

$\mathrm{Cr}^{51}$ is a soft $\mathrm{X}$-ray emitter with a half-life of 26.5 days. It disintegrates by $\mathrm{K}$ capture with transmutation to vanadium and emission of $\mathrm{X}$ rays of $4.92 \mathrm{Kev}$ plus a few per cent of 0.237 Mev gamma rays (3).

To prepare $\mathrm{Cr}^{51}$ from $\mathrm{Cr}^{50}$ in the pile with sufficiently high specific activity, ${ }^{4}$ it was necessary to enrich ordinary chromic oxide $\left(\mathrm{Cr}_{2} \mathrm{O}_{3}\right)$ electromagnetically. Naturally occurring chromium contains $4.49 \% \mathrm{Cr}^{50}$; the enriched chromium, $41.2 \%$. This enriched mixture was then irradiated in the Oak Ridge pile for two months, at the end of which

1 This work was supported in part by the United States Atomic Energy Commission, the Office of Naval Research, and the National Cancer Institute, U. S. Public Health Service.

2 This work was done in part during the tenure of a U. S. Public Health Service Postdoctorate Research Fellowship.

3 Courtesy of Harold C. Harrison.

4 The chromium 50 and 51 used in this investigation was supplied by the Isotopes Division, U. S. Atomic Energy Commission. time $100 \gamma$ of chromium contained 13 to 23 microcuries.

\section{METHODS}

\section{Preparation of $\mathrm{Na}_{2} \mathrm{Cr}^{51} \mathrm{O}_{4}$ (anionic hexavalent $\mathrm{Cr}^{51}$ )}

The chromium obtained from Oak Ridge was the dark green oxide $\left(\mathrm{Cr}_{2} \mathrm{O}_{3}\right)$. The oxide was triturated in a platinum crucible with a 1:5 mixture of $\mathrm{NaNO}_{3}$ and $\mathrm{Na}_{2} \mathrm{CQ}_{3}$ and fused several times by heating to redness with two Bunsen burners. After approximately two hours of fusion, the resulting yellow melt was dissolved in distilled water and filtered. The yellow alkaline $\mathrm{Na}_{2} \mathrm{Cr}^{51} \mathrm{O}_{4}$ solution was adjusted to $\mathrm{pH} 7.4$ by the dropwise addition of concentrated $\mathrm{HCl}$.

\section{Preparation of $\mathrm{Cr}^{51} \mathrm{Cl}_{3}$ (cationic trivalent $\mathrm{Cr}^{51}$ )}

$\mathrm{Na}_{2} \mathrm{Cr}^{51} \mathrm{O}$, solution was acidified with excess concentrated $\mathrm{HCl}$ and reduced with formaldehyde by boiling to fumes in a beaker on a hot plate. Distilled water was added to the dry salt and the resulting green solution of $\mathrm{Cr}^{51} \mathrm{Cl}_{3}$ was filtered and then adjusted to $\mathrm{pH} 4$ by the addition of $\mathrm{NaOH}$.

\section{Measurement of radioactivity}

An X-ray end window Geiger-Müller counter 5 was used for counting. It was tested with a standard $\mathrm{Fe}^{55}$ source having 26,180 disintegrations per minute of which it recorded 368 , or a counting efficiency of $1.4 \%$. Using the same geometry and assuming the same counting efficiency for the soft $\mathrm{X}$-rays of $\mathrm{Fe}^{55}$ and $\mathrm{Cr}^{51}, 1$ microcurie of chromium was computed to approximate 31,000 counts per minute.

The concentrated radioactive chromium solutions were diluted $1: 500$, and $1 \mathrm{cc}$. aliquots were pipetted into planchets and dried overnight. These planchets were retained as standards and were counted daily. The half-life obtained was in good agreement with the published value of 26.5 days (3). All samples were corrected for selfabsorption and radioactive decay.

On receipt from Oak Ridge, $100 \gamma$ of chromium emitted 403,000 to 713,000 counts per minute (13 to 23 microcuries). This amount of chromium was present in 0.18 cc. to $0.46 \mathrm{cc}$. of the original concentrated chromium solution.

\footnotetext{
${ }^{5}$ North American Phillips, tube type 62017-Amperex.
} 


\section{UPTAKE OF ANIONIC $\mathrm{Cr}^{51}\left(\mathrm{Na}_{2} \mathrm{Cr}^{51} \mathrm{O}_{4}\right)$ BY HUMAN RED BLOOD CELLS}

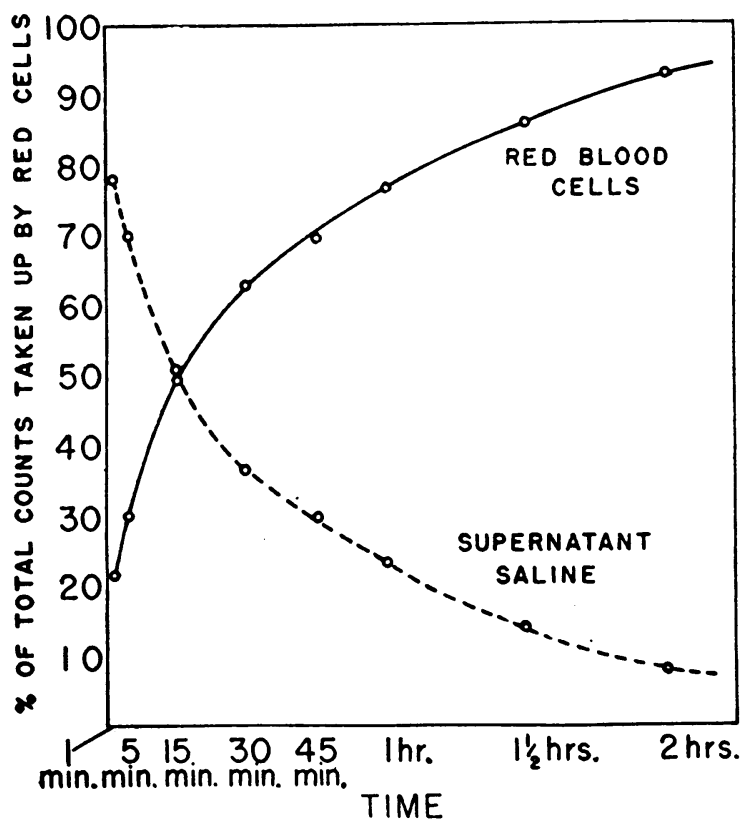

FIG. 1

\section{Procedure for counting radioactivity of tagged red cells and plasma}

Red cells: Red blood cells were dried and ground to a fine powder prior to counting. Whole blood or suspensions of red cells in saline were placed in $4 \mathrm{cc}$. hematocrit tubes and centrifuged at approximately 2,700 r.p.m. (741 g) for 60 minutes at $4^{\circ} \mathrm{C}$. The plasma or saline was withdrawn and the packed red blood cells were poured into unweighed aluminum planchets and dried overnight in an oven at $60^{\circ} \mathrm{C}$. This temperature was not exceeded, since chromium may sublime at $83^{\circ} \mathrm{C}$. Constant weight was achieved by this procedure. The dried caked red cell mass was ground to a fine powder with a pestle in a folded filter paper and counted in a weighed planchet.

One cc. of packed red blood cells, centrifuged to constant volume and measured in a calibrated pipette was found to weigh $0.35 \mathrm{gm}$. when dried to constant weight in an oven at $60^{\circ} \mathrm{C}$. The counts per cc. of packed red cells was computed from the counts contained in 0.35 gm. of dried ground red cells.

Plasma: One cc. of plasma was pipetted into a weighed planchet, dried overnight at $60^{\circ} \mathrm{C}$, and counted.

\section{UPTAKE OF RADIOACTIVE CHROMIUM BY THE RED BLOOD CELL}

\section{A. Anionic hexavalent chromium $\left(\mathrm{Na}_{2} \mathrm{Cr}^{51} \mathrm{O}_{4}\right)$}

The marked affinity of erythrocytes for chromate anion was demonstrated by the rapid uptake of radioactive chromium following the addition of $\mathrm{Na}_{2} \mathrm{Cr}^{51} \mathrm{O}_{4}$ to saline suspensions of washed red cells (Figure 1). Eighty-six $\gamma$ of chromium, as the chromate, was added to a series of $5 \mathrm{cc}$. aliquots of a saline suspension of washed erythrocytes with a hematocrit adjusted to 40 . After mixing in a mechanical shaker for periods ranging from one minute to two hours at room temperature, the suspensions were rapidly centrifuged; the supernatant saline and the red cells, washed three times, were prepared and counted. In a series of such experiments, $80-90 \%$ of the isotope was bound by the red cells within two hours (Figure 1).

A similar experiment, carried on for 43 hours, demonstrated the prolonged retention of radio-

UPTAKE OF ANIONIC $\mathrm{Cr}^{31}\left(\mathrm{NO}_{2} \mathrm{Cr}^{51} \mathrm{O}_{4}\right)$ BY HUMAN RED BLCOD CELLS

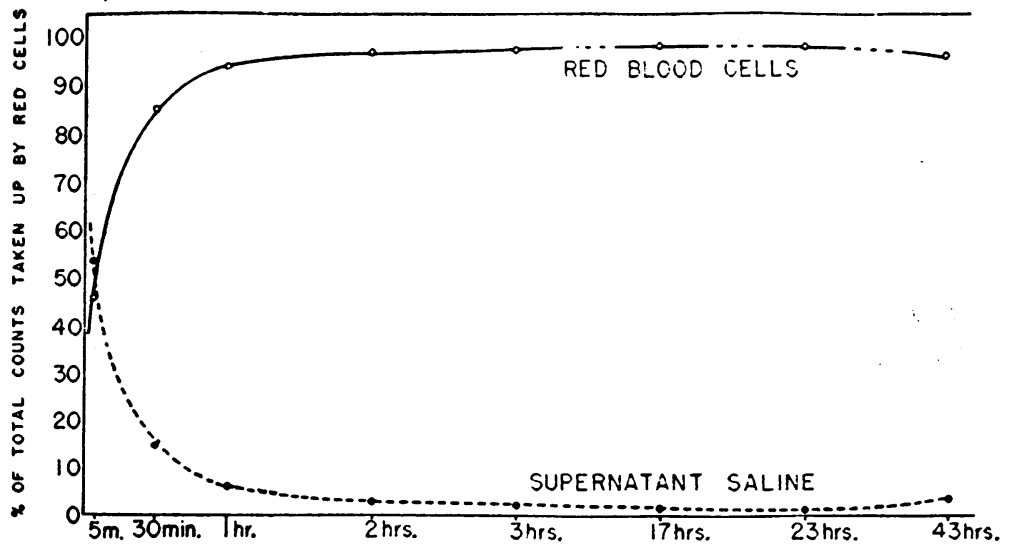

FIG. 1a 


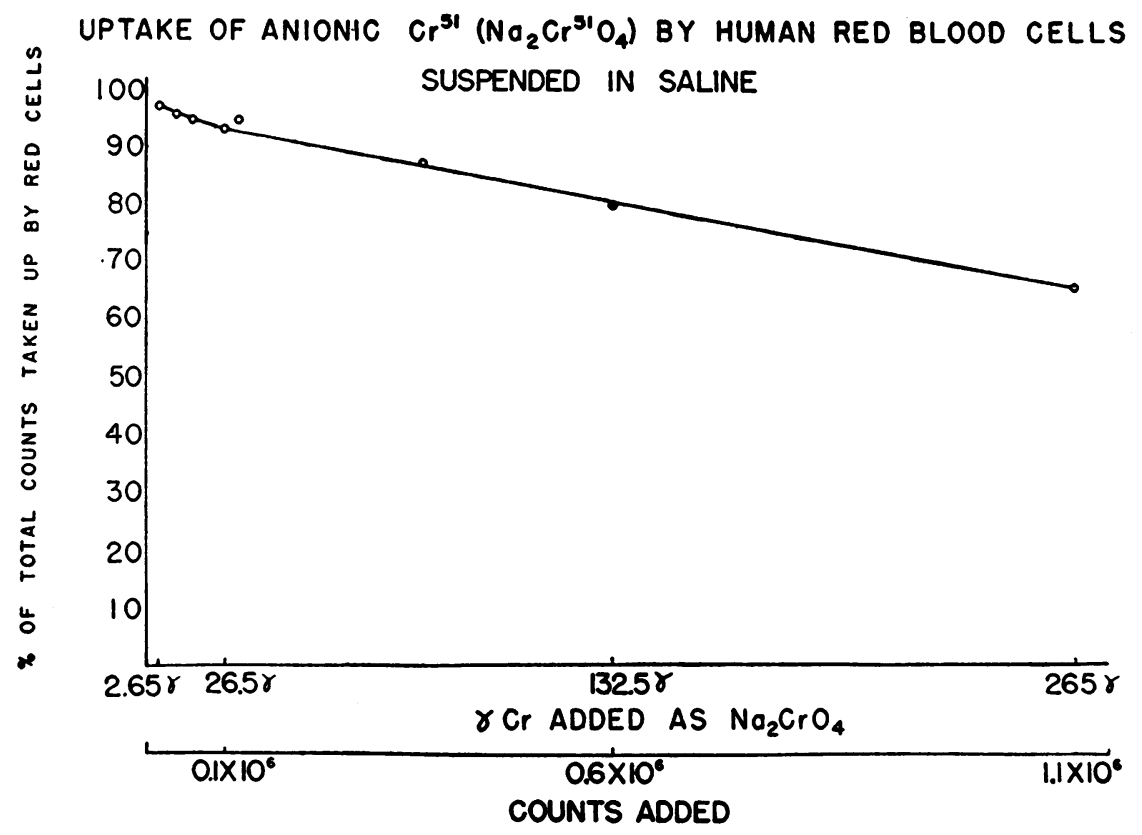

FIG. 2

activity by the red cells without significant loss to the saline medium (Figure 1a). Slight hemolysis had begun to occur at the end of this period.

Varying amounts of radioactive chromate were added to red cell suspensions and the percentage

$$
\begin{aligned}
& \text { UPTAKE OF ANIONIC } \mathrm{Cr}^{51}\left(\mathrm{No}_{2} \mathrm{Cr}^{31} \mathrm{O}_{4}\right) \\
& \hline \text { BY HUMAN RED BLOOD CELLS }
\end{aligned}
$$

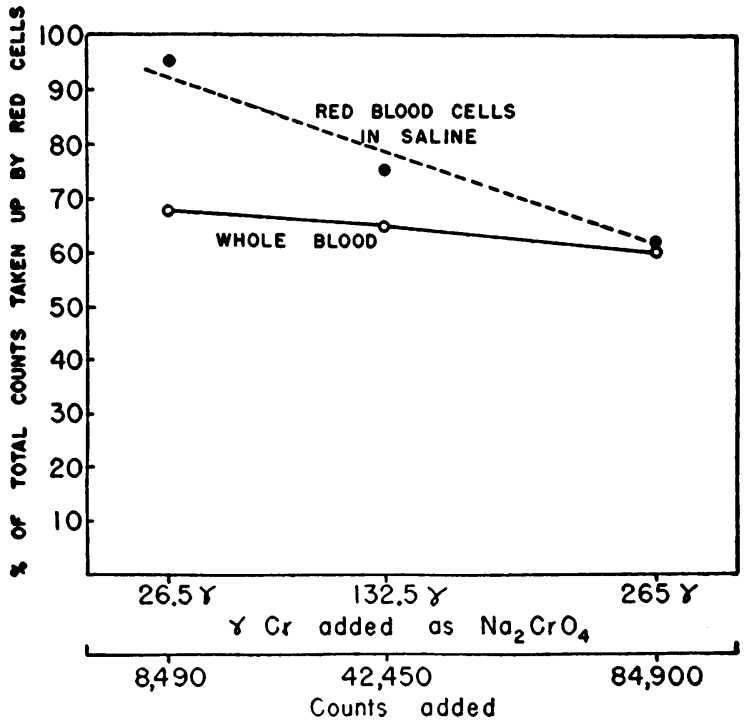

FIg. 2a uptake determined at the end of two hours. There was an inverse ratio between the amount of chromium added and the percentage uptake by the red blood cells (Figure 2). The addition of $2.65 \gamma$ of chromium to $5 \mathrm{cc}$. of red cell suspension resulted in $97.4 \%$ uptake of the total counts added. Successively larger amounts of chromium resulted in proportionately smaller percentage of red cell uptake, although the absolute amount of chromium bound was larger. Addition of $265 \gamma$ of chromium resulted in the uptake of $66.4 \%$ in the erythrocytes. These erythrocytes contained approximately 400 times the quantity of chromium found by chemical analysis in untreated red cells (2). One cc. of these packed red cells emitted 735,000 counts per minute or 23.7 microcuries.

Simultaneous uptake curves were determined with red cells in saline and whole blood from the same individual. The uptake by red cells in saline was appreciably greater than in whole blood (Figure 2a). The difference between the curves was attributed to binding of some of the chromium by the plasma proteins.

A similar affinity of the red cell for anionic hexavalent chromium was demonstrated in vivo by the intravenous injection of $\mathrm{Na}_{2} \mathrm{Cr}^{51} \mathrm{O}_{4}$ in the dog.

Figure 3 illustrates graphically the distribution 
of $\mathrm{Cr}^{51}$ in the red cells and plasma of a normal mongrel dog weighing 15.5 kilograms after the intravenous injection of $603 \gamma$ of chromium as $\mathrm{Na}_{2} \mathrm{Cr}^{51} \mathrm{O}_{4}$ emitting 4,788,800 counts per minute (155 microcuries). The findings are typical of four such experiments. The radioactivity of the blood was predominantly within the red cells. The plasma activity declined rapidly, and after two days the plasma contained only a small fraction of the radioactivity of the erythrocytes. The red cells, however, retained their radioactivity for a prolonged period, declining gradually but not showing a single exponential decay. There was a fall of $76 \%$ of the erythrocyte activity from the second to the 52nd day, which is approximately twice the rate of decline that could be attributed to the death of the red cell assuming a life span of 120 days (4) and the tagging of a mixed population of cells.

In view of the marked retention of radioactivity by the red cells, erythrocytes were tagged in vitro and re-injected into the same dog to determine whether the radioactivity would remain in the red cells in the animal's circulation.

Tagged red cells were prepared by the addition of 7-26 microcuries of $\mathrm{Na}_{2} \mathrm{Cr}^{51} \mathrm{O}_{4}$ to red cells with mixing for one hour at room temperature. The cells were then centrifuged and washed three times with cold physiological saline solution and finally resuspended in plasma from the same dog. The plasma radioactivity was found to be less than $0.5 \%$ of that of the red blood cells.

After the intravenous injection of this reconstituted whole blood containing the tagged red cells, consecutive blood samples were taken from the dog to determine the counts in the red cells and plasma. Figure 4 illustrates graphically the red cell radioactivity in one of ten such experiments. In all cases, the plasma contained no significant counts above background.

The activity of the red cells during the course of the day of injection agreed within the limits of the method. In ten dogs studied, the consecutive red cell activities at various intervals during the first day were in satisfactory agreement (5). A gradual decline of red cell activity was observed after the first day. The fall in 20 days was $53.6 \%$. This decline was again greater than that calculated from the life span of the red cell and apparently excludes the adaptation of the method to the direct measurement of red cell survival time.

Since the tagged red cells retained their radioactivity without significant loss to the plasma, a method for measuring the circulating red cell volume with $\mathrm{Cr}^{51}$ was devised, utilizing the quotient:

total counts injected in tagged red cells

counts per cc. packed red cells in sample

The stability of the red cell tagging was sufficient for such experiments to be continued for a period of 24 hours $(5,6)$.

\section{B. Cationic trivalent chromium $\left(\mathrm{Cr}^{51} \mathrm{Cl}_{3}\right)$}

The distribution of $\mathrm{Cr}^{51} \mathrm{Cl}_{3}$ in blood was found to differ considerably from that of $\mathrm{Na}_{2} \mathrm{Cr}^{51} \mathrm{O}_{4}$.

When varying amounts of $\mathrm{Cr}^{51} \mathrm{Cl}_{3}$ from $8 \gamma$ to $250 \gamma$ were added to $5 \mathrm{cc}$. aliquots of whole blood in vitro, almost all of the radioactivity (94-99\%)

\section{DISTRIaUtion OF ANMONIC Gen (No, Gren O)}

IN THE RED BLOOD CELLS AND PLASMA OF THE DOG

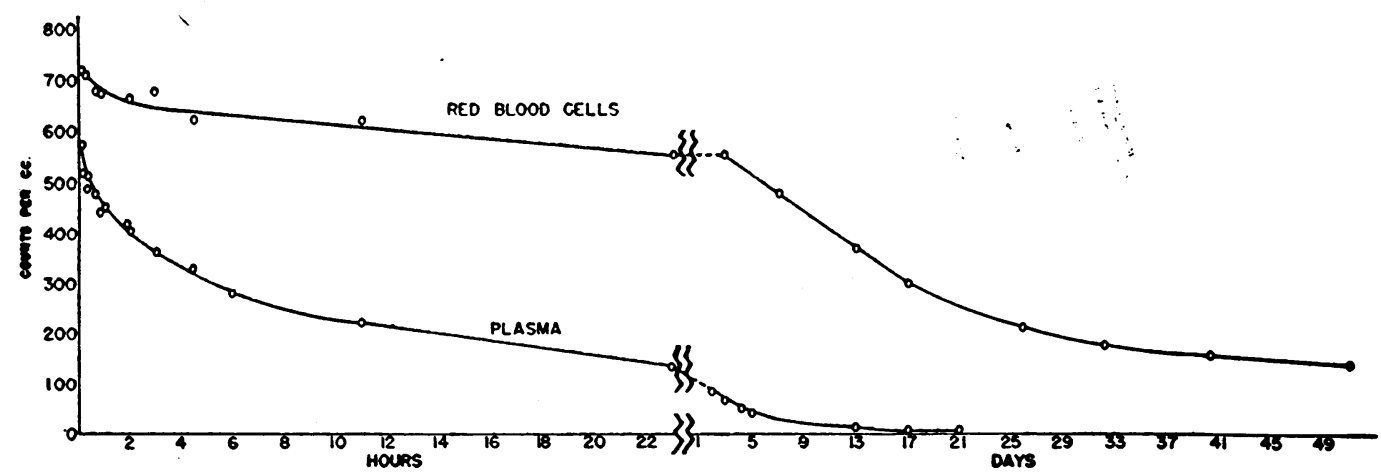

FIG. 3

Counts per cc. in the ordinate signifies counts per minute. 


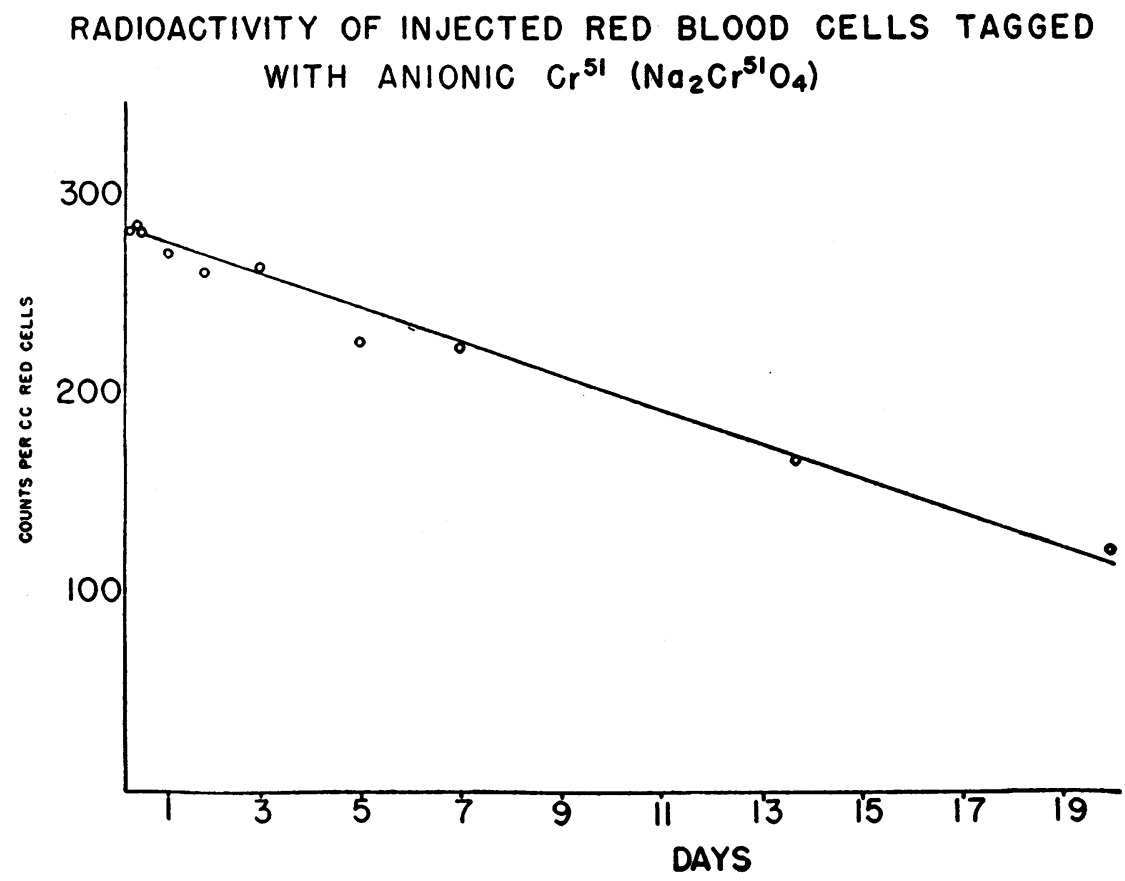

Fig. 4

Counts per cc. in the ordinate signifies counts per minute.

remained in the plasma and only insignificant counts were retained in the erythrocytes after saline washing. Similar results were obtained in vivo. After intravenous injection of $\mathrm{Cr}^{51} \mathrm{Cl}_{3}$ the radioactivity remaining in the animal's circulation was found exclusively in the plasma; the red cells manifested no significant uptake.

Figure 5 illustrates the distribution of radio- activity between the red cells and plasma of a normal mongrel dog weighing 15.0 kilograms after the intravenous injection of $906 \gamma$ of chromium as $\mathrm{Cr}^{51} \mathrm{Cl}_{8}$, emitting $6,324,150$ counts per minute (204 microcuries). The initial plasma activity within the first four hours after injection was more than 25 times greater than that of the washed red cells; the latter fell to negligible levels within

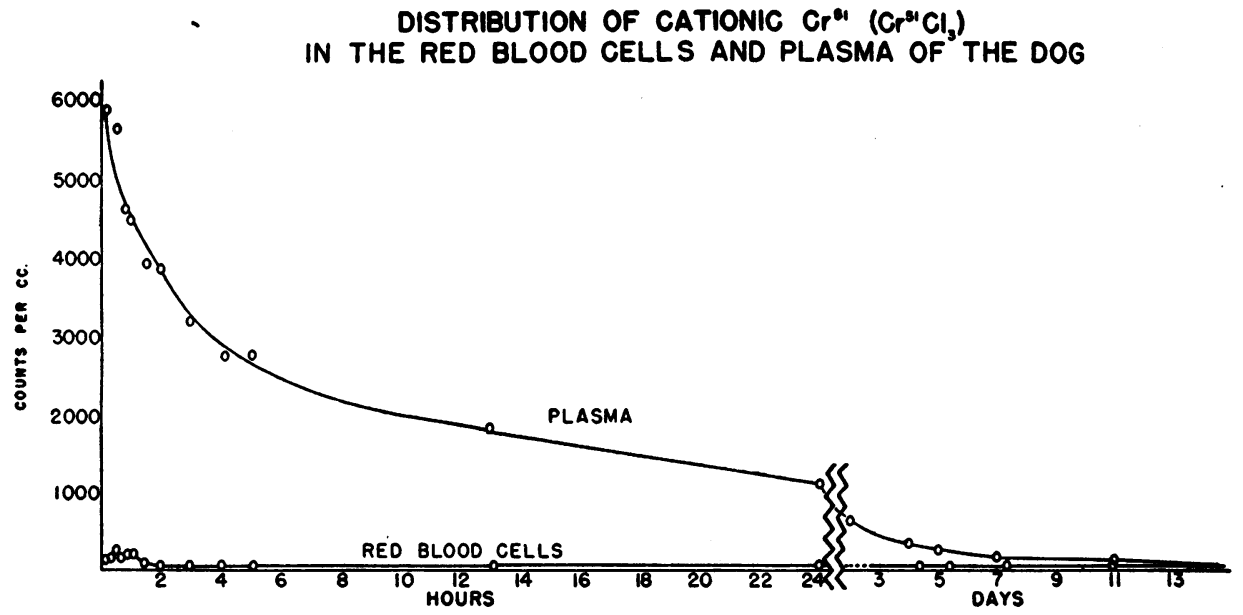

FIG. 5

Counts per cc. in the ordinate signifies counts per minute. 
four hours. From the second day on the plasma activity approximated an exponential decay with a three day half-time.

The inability of the erythrocyte to take up $\mathrm{Cr}^{51} \mathrm{Cl}_{8}$ could be explained by the relative impermeability of the red cell membrane to cationic chromium or the competitive binding by plasma proteins of this form of the isotope. To exclude the latter possibility, $\mathrm{Cr}^{51} \mathrm{Cl}_{3}$ was added to red cell suspensions in an isotonic acetate buffer at pH 5.5.

After two hours of mixing at room temperature, the washed erythrocytes contained only $1.6-2.7 \%$ of the counts added; approximately $98 \%$ of the radioactivity was recovered in the supernatant buffer.

\section{TAgGING OF PLASMA PROTEINS WITH RADIOACTIVE CHROMIUM}

\section{A. Cationic trivalent chromium $\left(\mathrm{Cr}^{31} \mathrm{Cl}_{3}\right)$}

In vivo experiments in dogs indicated that when $\mathrm{Cr}^{51} \mathrm{Cl}_{3}$ was injected intravenously, essentially all of the counts in the blood were retained in the plasma with insignificant activity within the erythrocytes. The fact that the plasma remained radioactive for periods exceeding ten days suggested the investigation of the plasma protein binding of $\mathrm{Cr}^{51} \mathrm{Cl}_{3}$.

A satisfactory protein for study was crystalline bovine albumin (Armour) since at its isoelectric point of 4.9 the chromic cation was in the soluble form. Radioactive $\mathrm{Cr}^{51} \mathrm{Cl}_{3}$ was added to a series of albumin solutions, each containing 5 micromoles (3.45 gm. \%). The molecular ratios of chromium to albumin in the series were $0.6: 1,1: 1$, $5: 1,10: 1,100: 1$. After four hours of mixing in the cold $\left(4^{\circ} \mathrm{C}\right)$, the albumin solutions were dialyzed against 2 liters of isotonic saline solution which was changed daily for three days. ${ }^{7}$ The

6 The acid acetate buffer was used instead of saline to prevent the precipitation of $\mathrm{Cr}(\mathrm{OH})_{3}$ which occurs at a higher $\mathrm{pH}$, resulting from the buffering action of the erythrocytes. The $\mathrm{pH}$ was maintained at 5.5 for the duration of the experiment and the precipitation of $\mathrm{Cr}(\mathrm{OH})_{\mathrm{s}}$ was avoided. This acid $\mathrm{pH}$ was shown not to prevent the usual erythrocyte uptake of anionic hexavalent chromium.

7 A control dialysis of comparably dilute $\mathrm{Cr}^{\mathrm{m}} \mathrm{Cl}_{8}$ solutions revealed that the dialysis was not complete, even after three days with mixing and daily change of dialy-
TABLE I

Binding of chromium $\left(\mathrm{Cr}^{\mathrm{bl}} \mathrm{Cl}_{3}\right)$ by crystalline bovine albumin

\begin{tabular}{c|c|c|c|c}
\hline \hline $\begin{array}{c}\text { Moles of } \mathrm{Cr} \\
\text { added per } \\
\text { mole of } \\
\text { albumin }\end{array}$ & $\begin{array}{c}\text { Counts percc. } \\
\text { of albumin } \\
\text { before } \\
\text { dialysis }\end{array}$ & $\begin{array}{c}\text { Counts percc. } \\
\text { of albumin } \\
\text { after } \\
\text { dialysis }\end{array}$ & $\begin{array}{c}\text { Per cent of } \\
\text { counts } \\
\text { retained }\end{array}$ & $\begin{array}{c}\text { Moles of } \mathrm{Cr} \\
\text { bound per } \\
\text { mole of } \\
\text { albumin }\end{array}$ \\
\hline 0.6 & 14,640 & 9,970 & 68.1 & 0.4 \\
1 & 21,400 & 14,950 & 69.9 & 0.7 \\
5 & 94,800 & 57,300 & 60.4 & 3.0 \\
10 & 48,200 & 26,800 & 55.6 & 5.6 \\
100 & 31,900 & 12,500 & 39.2 & 39.2 \\
\hline
\end{tabular}

radioactivity per cc. of albumin solution was determined before and after dialysis (Table I). As increasing amounts of chromium were added, the per cent of radioactivity retained after dialysis decreased, although the absolute amount of chromium bound increased. No stoichiometric relationship was observed; the number of moles of chromium bound per mole of albumin depended upon the amount of chromium added. When 1 mole of chromium was added to 1 mole of albumin, approximately $70 \%$ of the chromium was bound.

The ability of the albumin to retain its radioactivity over a period of time was determined by prolonged dialysis over periods up to 17 days. There was little or no further decline in radioactivity following additional dialysis.

The addition of excess non-radioactive chromium to the fluid outside the dialyzing bag produced only a very small loss of radioactivity. Approximately $2 \%$ of the counts were recovered in the outside fluid. This further illustrates the firmness of the chromium-protein bond, since the bound radioactive chromium did not exchange appreciably with the newly added non-radioactive chromium.

Visible changes indicating denaturation, such as discoloration and solidification, occurred after dialysis of 100 moles of chromium and 10 moles of chromium mixed with 1 mole of albumin. Solutions containing 5 moles or less of chromium with 1 mole of albumin revealed no change in appearance after several months' storage at $4^{\circ} \mathrm{C}$.

Physicochemical analyses of chromium-tagged albumin did not disclose significant alterations from the native state of the protein. A sample of crystalline bovine albumin which had bound 0.5

sate. The errors to be anticipated because of this were of the order of $10 \%$ or less. In contrast, $\mathrm{Na}_{2} \mathrm{Cr}^{\mathrm{m}} \mathrm{O}$, was dialyzed completely by this technique. 
mole of chromium per mole of albumin was analyzed in the ultracentrifuge and by electrophoresis. ${ }^{8}$ In the ultracentrifuge, the tagged albumin was homogenous and showed no change from untreated albumin. The electrophoretic mobility was $-7.6 \times 10^{-5} \mathrm{~cm}^{2} /$ volt $/ \mathrm{sec}$. Samples taken from portions of the electrophoretic cell from which the protein had migrated revealed no radioactivity, indicating that no chromium had been detached from the protein during electrophoresis. The ultracentrifugal and electrophoretic data for the tagged albumin did not differ from the native bovine albumin. One gm. of this $\mathrm{Cr}^{31}$-tagged albumin emitted 925,000 counts per minute (29.9 microcuries).

In addition to albumin, other protein fractions including gamma globulin, beta metal combining protein, and beta lipoprotein were found to bind trivalent chromium. Chromium-tagged crystalline bovine albumin was mixed with an equal amount of untagged bovine gamma globulin, and the mixture was allowed to stand 22 days in the cold. When the proteins were separated by electrophoresis, almost all of the radioactivity remained in the albumin with only $2.7 \%$ in the gamma globulin fraction.

Binding of chromic ion to protein may involve initially a polar attraction by carboxyl groups. The firm attachment may be explained by coordinate covalent bonds of the type of $\mathrm{Cr}\left(\mathrm{NH}_{3}\right)_{6}{ }^{+++}$ between the chromium and terminal amino groups of lysine or other basic groups of the protein. This would be analogous to hypotheses of the linkage of chromium to collagen in leather tanning (7).

\section{B. Anionic hexavalent chromium $\left(\mathrm{Na}_{2} \mathrm{Cr}^{51} \mathrm{O}_{4}\right)$}

The addition of the anionic hexavalent form of chromium $\left(\mathrm{Na}_{2} \mathrm{Cr}^{51} \mathrm{O}_{4}\right)$ to proteins also resulted in tagging, but to a considerably less extent than was achieved with the cationic trivalent form $\left(\mathrm{Cr}^{51} \mathrm{Cl}_{3}\right)$. When $\mathrm{Na}_{2} \mathrm{Cr}^{51} \mathrm{O}_{4}$ was added to crystalline bovine albumin and dialyzed, the binding was only $14 \%$ of that attained by the addition of an equal amount of $\mathrm{Cr}^{51} \mathrm{Cl}_{3}$.

The diminished uptake of $\mathrm{Na}_{2} \mathrm{Cr}^{51} \mathrm{O}_{4}$ by the erythrocytes in whole blood as compared to red cell suspensions in saline (Figure $2 \mathrm{a}$ ) further sug-

\footnotetext{
${ }^{8}$ Courtesy of Charles Gordon, M. J. E. Budka and Dr. J. L. Oncley.
}

gested plasma protein binding. The possibility that hexavalent chromium may be reduced to the trivalent state in the process of protein binding will be discussed below.

\section{MECHANISM OF RED CELL UPTAKE OF CHROMIUM}

\section{A. Effect of non-radioactive chromate upon red cell tagging}

The firm binding of $\mathrm{Na}_{2} \mathrm{Cr}^{51} \mathrm{O}_{4}$ by red blood cells was investigated further by determining the effect of non-radioactive chromate upon the radioactivity of the tagged cells.

Radioactive $\mathrm{Na}_{2} \mathrm{Cr}^{51} \mathrm{O}_{4}$ (106 $\gamma$ of chromium) was mixed with a red cell suspension for two hours at room temperature and the counts per cc. of packed red blood cells were determined. An excess of non-radioactive chromate $(200 \gamma$ of chromium) was then added to a duplicate suspension, and the red cell activity was determined one hour later. There was no loss of radioactivity after the addition of non-radioactive chromate to the red cell suspension, indicating that anionic chromium, once bound by the erythrocyte, did not leave the cells and exchange with the outside medium for the duration of the experiment. The marked contrast between the firm erythrocyte binding of $\mathrm{Cr}^{51}$ and the rapidly reversible exchange observed with $\mathrm{P}^{32}(8,9)$ suggests a different mechanism of tagging.

\section{B. Kinetics of uptake of $\mathrm{Na}_{2} \mathrm{Cr}^{51} \mathrm{O}_{4}$ by red cells}

The kinetics of the uptake of $\mathrm{Na}_{2} \mathrm{Cr}^{51} \mathrm{O}_{4}$ by red cells in saline (Figure 1) were analyzed and suggested that sodium chromate diffused through the cell membrane and was then bound firmly. When the dotted line curve of Figure 1 representing counts remaining in the saline solution was plotted on semi-logarithmic paper, the points approximated a straight line (Figure 6 ). The relation may be expressed by :

$$
\mathrm{C}_{\mathrm{S}}=\mathrm{C}_{\mathrm{T}} \mathrm{e}^{-\lambda t} \text {, }
$$

where $C_{s}=$ counts remaining in saline phase at time " $t$ "

$\mathrm{C}_{\mathbf{T}}=$ total counts in the system

$\lambda=$ rate of binding of chromium by the red cells

$\mathbf{t}=$ time in minutes. 
Adherence to this standard equation for first order reactions indicated that under the conditions of the experiment, i.e., excess of red cells compared to chromium concentration, the rate of disappearance of chromium from the saline was proportional to the concentration of chromium remaining in the saline. The slope of the line was an index of the rate of binding of chromium by the red cells. The fall of activity of the saline to $10 \%$ of the initial level in two hours suggested firm binding of chromium within the red cells. Two $\%$ of the chromium remaining in the saline was bound per minute, as computed from Figure 6 . The half-time of the chromium binding was 38 minutes. These findings were typical of five such experiments performed under the same conditions.

\section{Fractionation of red blood cells previously tagged with $\mathrm{Na}_{2} \mathrm{Cr}^{51} \mathrm{O}_{4}$}

To ascertain what component of the erythrocyte contained the radioactivity, red blood cells previously tagged with $\mathrm{Na}_{2} \mathrm{Cr}^{51} \mathrm{O}_{4}$ were fractionated into stroma-free hemoglobin, globin $\mathrm{HCl}$, hemin, and washed stroma ${ }^{\circ}(10-12)$ and the radioactivity

${ }^{9}$ Courtesy of Dr. R. B. Pennell.

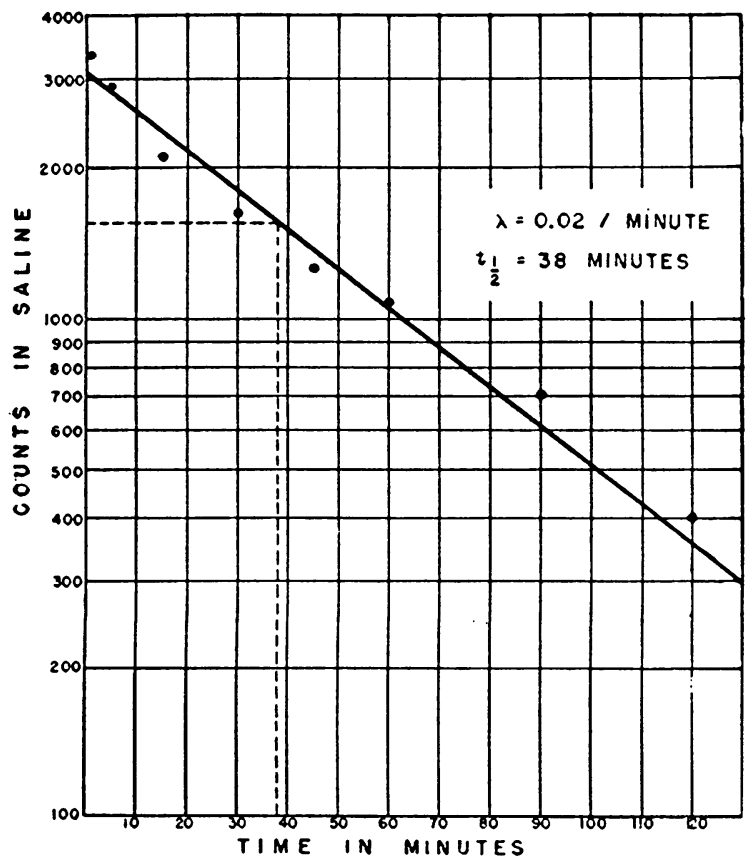

FIG. 6

Counts per cc. in the ordinate signifies counts per minute.
TABLE II

Fractionation of red blood cells previously tagged with $\mathrm{Na}_{2} \mathrm{Cr}^{51} \mathrm{O}_{4}$

\begin{tabular}{lcc}
\hline \hline Blood fraction & $\begin{array}{c}\text { Counts calculated } \\
\text { on the basis of } \\
\text { cc. packed red cells }\end{array}$ & $\begin{array}{c}\text { Per-cent } \\
\text { of counts }\end{array}$ \\
\hline Red blood cells & 19,700 & per cent \\
Hemoglobin (stroma-free) & 19,150 & 97 \\
Globin HCl & 15,400 & 78 \\
Hemin & 0 & 0 \\
Washed stroma & 398 & 2 \\
\hline
\end{tabular}

of the intact red cells and the red cell fractions was compared. The counts were calculated on the basis of $1 \mathrm{cc}$. of packed red cells ${ }^{10}$ (Table II).

The activity of the hemoglobin (stroma-free) was $97 \%$ of that of the red cells, indicating that hemoglobin was the important factor in red cell binding (Table II). The recovery of $78 \%$ of the activity in the globin fraction and only a trace in hemin suggests binding of the chromium by the globin portion of hemoglobin. (Approximately $19 \%$ of the activity was lost in fractionating the hemoglobin to globin and hemin.) The presence of only $2 \%$ of the radioactivity in the washed stroma confirms the importance of hemoglobin in red cell uptake.

When stroma-free hemoglobin was prepared from red cells previously tagged with $\mathrm{Na}_{2} \mathrm{Cr}^{51} \mathrm{O}_{4}$ and then dialyzed against saline for three days, $68.5 \%$ of the radioactivity remained with the hemoglobin within the bag. The tagged hemoglobin, moreover, retained its activity after 24 hours of mixing with a combination of anionic and cationic exchange resins capable of removing all of the chromium present. ${ }^{11}$

\section{Uptake of radioactive chromium by red cell fractions}

The mechanism of erythrocyte uptake was investigated further by the addition of radioactive chromium to the stroma and hemoglobin fractions of red cells (Table III). The quantitative relationships of radioactive chromium to intact red

10 The weight of hemoglobin was taken as $98 \%$ of the weight of dried red cells, and the stroma as $2 \%$. Since hemin with a molecular weight of 615 constitutes $9.05 \times$ $10^{-3} \times$ weight of hemoglobin (molecular weight 68,000 ), the weight of globin was considered essentially the same as hemoglobin.

11 Ionac C240, A-300 (Cyanamid Company), Dowex and Amberlite. 
TABLE III

Uptake of radioactive chromium by red cell fractions

\begin{tabular}{|c|c|c|c|c|c|}
\hline Red cell fraction & Form of isotope added & pH after dialysis & $\begin{array}{l}\text { Counts added to the } \\
\text { fraction present in } 1 \text { cc. of } \\
\text { packed red cells }\end{array}$ & $\begin{array}{l}\text { Counts bound by the } \\
\text { fraction present in } 1 \text { cc. of } \\
\text { packed red cells }\end{array}$ & Per cent uptake \\
\hline $\begin{array}{l}\text { Stroma } \\
\text { Hemoglobin } \\
\text { Hemoglobin } \\
\text { Hemoglobin }\end{array}$ & $\begin{array}{l}\mathrm{Na}_{2} \mathrm{Cr}^{51} \mathrm{O}_{4} \\
\mathrm{Na}_{2} \mathrm{Cr}^{51} \mathrm{O}_{4} \\
\mathrm{Na}_{2} \mathrm{Cr}^{51} \mathrm{O}_{4} \\
\mathrm{Cr}^{51} \mathrm{Cl}_{3}\end{array}$ & $\begin{array}{l}7.2 \\
4.5 \\
4.5\end{array}$ & $\begin{array}{l}5,399 \\
6,136 \\
6,360 \\
7,840\end{array}$ & $\begin{array}{l}158.5 \\
1,388 \\
2,088 \\
4,528\end{array}$ & $\begin{array}{r}2.9 \\
22.6 \\
32.8 \\
57.8\end{array}$ \\
\hline
\end{tabular}

cells described previously (Figure 1) were essentially maintained in all the experiments with erythrocyte fractions.

The stroma, washed free of hemoglobin, did not bind significant amounts of chromium (Table III). The addition of $53 \gamma$ of chromium as $\mathrm{Na}_{2} \mathrm{Cr}^{51} \mathrm{O}_{4}$ to the stroma content of $1 \mathrm{cc}$. of packed red cells ( $7 \mathrm{mg}$. of stroma) resulted in the uptake of only $2.9 \%$ of the counts.

The binding capacity of the hemoglobin for the anionic and cationic forms of chromium was studied by determining the radioactivity of tagged hemoglobin solutions after dialysis.

Radioactive chromium $\left(\mathrm{Na}_{2} \mathrm{Cr}^{51} \mathrm{O}_{4}\right.$ and $\left.\mathrm{Cr}^{51} \mathrm{Cl}_{8}\right)$ was added to $7 \%$ hemoglobin solutions in concentrations of $150 \gamma$ of chromium per gram of hemoglobin. The solutions were mixed at room temperature for two hours and then dialyzed in the cold for three days with daily changes of dialysate. The solution tagged with $\mathrm{Cr}^{51} \mathrm{Cl}_{3}$ was dialyzed against acetate buffer at $\mathrm{pH} 4.5$ to prevent precipitation of $\mathrm{Cr}(\mathrm{OH})_{3}$, and the hemoglobin solutions containing $\mathrm{Na}_{2} \mathrm{Cr}^{51} \mathrm{O}_{4}$ were dialyzed against the same buffer at $\mathrm{pH} 4.5$ and against saline at $\mathrm{pH}$ 7.2 .

Hemoglobin, in contrast to stroma, revealed a significant affinity for radioactive chromium (Table III). It is of considerable interest that the uptake was greater with $\mathrm{Cr}^{51} \mathrm{Cl}_{3}$ than with $\mathrm{Na}_{2} \mathrm{Cr}^{51} \mathrm{O}_{4}$, emphasizing again that the inability of $\mathrm{Cr}^{51} \mathrm{Cl}_{3}$ to tag the intact red cell is a reflection of the relative impermeability of the red blood cell to cations.

\section{COMMENT}

A marked affinity of the red cell for anionic hexavalent chromium $\left(\mathrm{Na}_{2} \mathrm{Cr}^{51} \mathrm{O}_{4}\right)$ has been demonstrated both in vitro and in vivo. The site of tagging appeared to be within the hemoglobin of the erythrocyte, in particular the globin fraction; only $2 \%$ of the counts were recovered in the washed stroma. Although the intact red cell did not take up a significant amount of cationic trivalent chromium $\left(\mathrm{Cr}^{51} \mathrm{Cl}_{3}\right)$ in vivo or in vitro, the hemoglobin solution was capable of binding $57.8 \%$ of the $\mathrm{Cr}^{51} \mathrm{Cl}_{3}$ added to it. The failure of $\mathrm{Cr}^{51} \mathrm{Cl}_{3}$ to tag the intact erythrocyte is attributed to the relative impermeability of the red cell membrane to cations.

Comparison of the binding capacity of hemoglobin for cationic trivalent and anionic hexavalent chromium, moreover, revealed a significantly greater uptake of cationic $\mathrm{Cr}^{15} \mathrm{Cl}_{3}$. In view of the rapid and firm binding of anionic $\mathrm{Na}_{2} \mathrm{Cr}^{51} \mathrm{O}_{4}$ by the erythrocyte, it is suggested that anionic hexavalent chromium diffuses readily through the cell membrane and is bound by the hemoglobin, probably after reduction to the cationic trivalent state within the red cell.

In the foregoing experiments with red cell fractions, the hemoglobin was not necessarily free of other protein components of the red cell, including the enzymes. It was, however, considered unlikely that enzymes played a major role in the actual binding by the red cell. In the usual red cell uptake studies, $120-170 \gamma$ of chromium were added per gram of hemoglobin, resulting in an uptake of 0.13-0.23 mole of chromium per mole of hemoglobin. It was not believed likely that minute quantities of enzymes could bind this much chromium, but a possible enzymatic reduction of hexavalent to trivalent chromium within the erythrocyte was not excluded.

Further studies of the metabolism of chromium and its distribution in the body are in progress.

\section{SUM MARY}

1. A new biological tracer, radioactive chromium $\left(\mathrm{Cr}^{51}\right)$ with a half-life of 26.5 days, was found to tag both red blood cells and plasma proteins. 
2. The anionic hexavalent form of the isotope $\left(\mathrm{Na}_{2} \mathrm{Cr}^{51} \mathrm{O}_{4}\right)$ labelled red blood cells while the cationic trivalent form $\left(\mathrm{Cr}^{51} \mathrm{Cl}_{3}\right)$ was firmly bound by plasma proteins.

3. The addition, in vitro, of $86 \gamma$ of chromium as the chromate to a $5 \mathrm{cc}$. suspension of red cells in saline resulted in an uptake of $80-90 \%$ of the radioactivity within two hours.

4. The intravenous injection of $\mathrm{Na}_{2} \mathrm{Cr}^{51} \mathrm{O}_{4}$ in dogs resulted in a rapid tagging of the red cells which retained their radioactivity for a prolonged period, while the plasma activity fell rapidly.

5. Washed red cells, tagged with $\mathrm{Na}_{2} \mathrm{Cr}^{51} \mathrm{O}_{4}$ in vitro, were injected intravenously into dogs and retained their activity without significant loss to the plasma for approximately 24 hours.

6. The site of tagging of the erythrocyte with $\mathrm{Na}_{2} \mathrm{Cr}^{51} \mathrm{O}_{4}$ appeared to be the globin portion of hemoglobin.

7. Hemoglobin demonstrated a significantly greater binding capacity for $\mathrm{Cr}^{51} \mathrm{Cl}_{3}$ than for $\mathrm{Na}_{2} \mathrm{Cr}^{51} \mathrm{O}_{4}$.

8. Cationic trivalent chromium, in contrast to anionic hexavalent chromium, was not taken up by the red blood cells, presumably because of the relative impermeability of the cell membrane to the cation.

9. It is suggested that anionic hexavalent chromium diffuses through the red cell membrane and is bound by hemoglobin within the cell probably after reduction to the cationic trivalent state, resulting in the firm tagging of the erythrocyte.

10. An albumin solution labelled with $\mathrm{Cr}^{51} \mathrm{Cl}_{3}$ contained 29.9 microcuries per gram after dialysis and did not differ from native albumin by ultracentrifugal and electrophoretic analyses.

\section{ACKNOWLEDGMENTS}

The authors gratefully acknowledge the helpful suggestions of Doctors Arthur $\mathrm{K}$. Solomon, Charles V. Robinson, Isadore S. Edelman, Walter L. Hughes, Jr., and John L. Oncley.
Harold A. Papazian and Madison B. Whittier rendered valuable technical assistance.

\section{BIBLIOGRAPHY}

1. Monier-Williams, G. W., Trace Elements in Food. John Wiley \& Sons, New York, 1949, pp. 439-443.

2. Gray, S. J., Mitchell, A. M., and Sterling, K., The colorimetric determination of trace amounts of chromium in tissues. To be published.

3. Bradt, H., Gugelot, P. C., Huber, O., Medicus, H., Preiswerk, $P$., and Scherrer, $P$., Die radioaktive Umwandlung des $\mathrm{Cr}^{\text {52 }}$. Helvet. physiol. acta, 1945, 18, 252.

4. Bale, W. F., Yuile, C. L., De La Vergne, L., Miller, L. L., and Whipple, G. H., Hemoglobin labeled by radioactive lysine; erythrocyte life cycle. J. Exper. Med., 1949, 90, 315.

5. Gray, S. J., and Sterling, K., Determination of circulating red cell volume by radioactive chromium. Science, 1950, 112, 179.

6. Sterling, K., and Gray, S. J., Determination of the circulating red cell volume in man by radioactive chromium. J. Clin. Invest., 1950, 29, 1614.

7. Gustavson, K. H., Some protein-chemical aspects of tanning processes, in Advances in Protein Chemistry, edited by Anson, M. L., and Edsall, J. T. Academic Press, New York, 1949, Vol. 5, p. 354.

8. Hevesy, G., Köster, K. H., S $\phi$ rensen, G., Warburg, E., and Zerahn, K., The red corpuscle content of the circulating blood determined by labeling the erythrocytes with radio-phosphorus. Acta med. Scandinav., 1944, 116, 561.

9. Reeve, E. B., and Veall, N., A simplified method for the determination of circulating red-cell volume with radioactive phosphorus. J. Physiol., 1949, 108, 12.

10. Anson, M. L., and Mirsky, A. E., Protein coagulation and its reversal; preparation of insoluble globin, soluble globin and heme. J. Gen. Physiol., 1930, 13, 469.

11. Bernstein, S. S., Jones, R. L., Erickson, B. N., Williams, H. H., Avrin, I., and Macy, I. G., A method for the preparation of posthemolytic residue or stroma of erythrocytes. J. Biol. Chem., 1937-38, 122, 507.

12. Pennell, R. B., Smith, W. E., and Werkheiser, W. C., Preparation of hemoglobin solutions containing hemoglobin reducing enzymes. Proc. Soc. Exper. Biol. \& Med., 1947, 65, 295. 